\section{Large Hadron Collider passes first proton test}

The world's largest particle accelerator has tasted its first protons.

On 8 August, physicists injected a few billion protons into a section of the Large Hadron Collider (LHC) at CERN, Europe's high-energy physics laboratory near Geneva, Switzerland. The accelerator will eventually drive trillions of protons into each other at energies high enough to perhaps generate new kinds of particles.

The small beam tested the synchronization between the LHC and a booster accelerator. "I must say I was very pleased," says Lyn Evans, LHC project leader at CERN. "It went extremely smoothly."

Further tests will be carried out in coming weeks, with a view to having protons running laps around the 27-kilometre LHC ring by 10 September.

\section{Environment agency denies plea to cut biofuel goals}

The US Environmental Protection Agency (EPA) last week upheld the national mandate to use biofuels. The decision was made despite opposition from livestock and environmental groups, which say that the expansion of corn (maize) ethanol is pushing up food prices and damaging the environment.

EPA administrator Stephen Johnson denied the request of Rick Perry, the Republican governor of Texas, to halve the 'renewable fuels standard', which requires the nation to produce 34 billion litres of ethanol in 2008. Perry had argued that livestock producers in his state spent an additional US $\$ 1.2$ billion on corn feed between 2004 and 2007, a trend that he linked to the expansion of biofuels.

But Johnson says that repealing the standard would do little, if anything, to bring corn prices down. He also says that the EPA's analysis found no evidence that the mandate is damaging the national economy. For a longer version of this story, see http://tinyurl. com/5hr3jv.

\section{San Francisco's biotech hub gets lift from Pfizer deal}

San Francisco's drive to turn the Mission Bay area into a technology-transfer hub has been boosted by Pfizer's decision to move one of its research centres to the site.

In early 2010, the Biotherapeutics and Bioinnovation Center will move into newly constructed lab facilities near the Mission Bay research complex run by the University of California, San Francisco. About 100 of the centre's employees will move there from its current base in South San Francisco.

Five years after the university opened facilities at Mission Bay, biotech firms are finally trickling in. In June, Pfizer, which is headquartered in New York, agreed a US\$9.5-million, three-year deal for research collaborations with Mission Bay's California Institute for Quantitative Biosciences.

\section{Gorilla numbers doubled in the Congo}

Western lowland gorillas (Gorilla gorilla gorilla) are more common than previously thought, according to a census of the northern regions of the Republic of the Congo. Led by the New-York-based Wildlife Conservation Society (WCS), the count found 125,000 of the apes in a 47,000square-kilometre area. Previous estimates held that there were fewer than 100,000

\title{
Hotspot for midges proves to be fertile ground
}

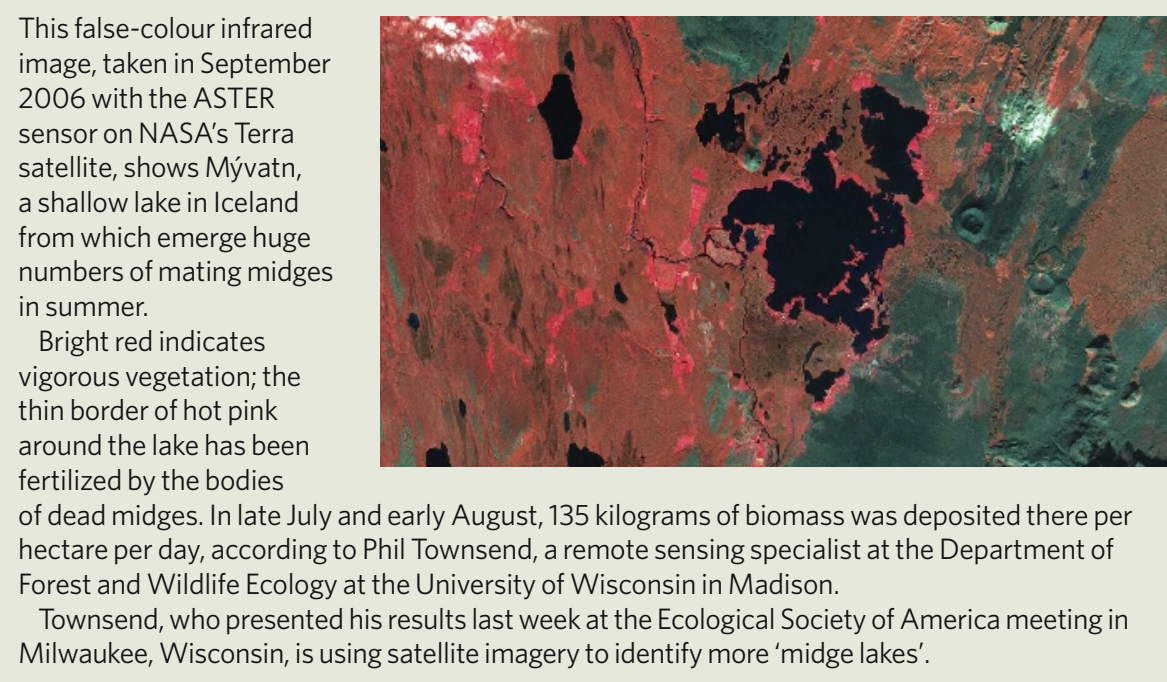

This false-colour infrared image, taken in September 2006 with the ASTER sensor on NASA's Terra satellite, shows Mývatn a shallow lake in Iceland from which emerge huge numbers of mating midges in summer.

Bright red indicates vigorous vegetation; the of dead midges. In late July and early August, 135 kilograms of biomass was deposited there per hectare per day, according to Phil Townsend, a remote sensing specialist at the Department of

Milwaukee, Wisconsin, is using satellite imagery to identify more 'midge lakes'.

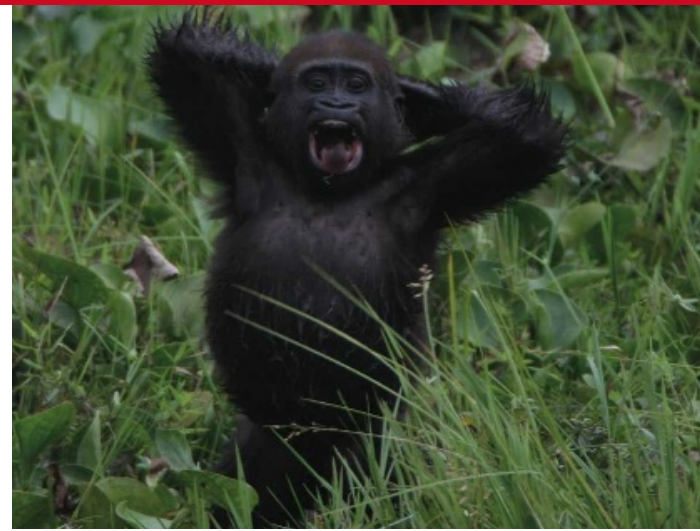

western lowland gorillas in the entire world, and the International Union for Conservation of Nature has speculated that the Ebola virus could have reduced numbers even further.

Census-takers counted the gorillas' sleeping nests. The WCS attributes the high numbers to successful management of protected areas in the Republic of the Congo, a food-rich habitat and the "remoteness and inaccessibility" of the region. The work was presented at the International Primatological Society Congress in Edinburgh, UK.

Even so, a separate global assessment presented at the same conference reports that half of primate species are threatened with extinction in the next ten years.

For a longer version of this story, see http://tinyurl. com/68ewes

\section{FDA further tightens conflict of interest policies}

The US Food and Drug Administration (FDA) is introducing guidelines to reduce potential conflicts of interest among members of its advisory committees.

In part, the regulations address a 2007 law that requires the agency to cut the number of advisers who have conflicts of interest by onequarter over the next five years. According to the guidelines, committee members may not have financial ties to the topics under consideration. Those with financial interests totalling less than $\$ 50,000$ would be eligible for waivers allowing them to participate.

The guidelines also instruct members of committees to vote simultaneously. Previously, members stated their votes aloud in succession, which could influence later voters. In addition, the FDA intends to make information about committee activities more accessible by posting related documents on its website prior to meetings.

\section{SCIFOO BLOGGED}

Last week saw the 2008 SciFoo, the annual 'unconference' organized by Nature, Tim O'Reilly and Google. Topics ranged from the Large Hadron Collider to the neuroscience of the brainmachine interface and a new social contract for science. Details and participants are at www.nature.com/scifoo. 